\title{
Polikistik Over Sendromlu Hastalarda İnsülin Direnci ve Eser Elementlerin İlişkisi
}

\section{The Relationship between Insulin Resistance and Trace Elements in Patients with Polycystic Ovary Syndrome}

\author{
${ }^{1}$ Ragip BALAHOROGLU, ${ }^{2}$ Ali Kemal ZIREK, ${ }^{3}$ Erdem COKLUK, ${ }^{4}$ Murat ATMACA, \\ ${ }^{3}$ Mehmet Ramazan SEKEROGLU, ${ }^{2}$ Zubeyir HUYUT
}

\author{
${ }^{1}$ Department of Biochemistry, Konya Trainning and Research Hospital, Konya, Turkey \\ ${ }^{2}$ Department of Biochemistry, Medical Faculty, Yüzüncü Yıl University, Van, Turkey \\ ${ }^{3}$ Department of Biochemistry, Medical Faculty, Sakarya University, Sakarya, Turkey \\ ${ }^{4}$ Department of Endocrinology, Medipol University Hospital, İstanbul, Turkey \\ Ragip Balahoroglu: https://orcid.org/0000-0003-4623-6548 \\ Ali Kemal Zirek: https://orcid.org/0000-0002-7881-7251 \\ Erdem Cokluk: https://orcid.org/0000-0002-6205-5109 \\ Murat Atmaca: https://orcid.org/0000-0003-4075-4686 \\ Mehmet Ramazan Sekeroglu: https://orcid.org/0000-0001-8383-6740 \\ Zubeyir Huyut: https://orcid.org/0000-0002-7623-1492
}

\begin{abstract}
ÖZ
Amaç: $\mathrm{Bu}$ çalışma, polikistik over sendromunda (PKOS) hormon düzeyleriyle çinko $(\mathrm{Zn})$, krom $(\mathrm{Cr})$, kobalt $(\mathrm{Co})$ ve mangan $(\mathrm{Mn})$ konsantrasyonlarının ilişkisini incelemek için tasarlanmıştır.

Materyal ve Metot: Çalışmaya endokrinoloji polikliniğine başvuran 18-40 yas arası PKOS teşhisi konulan 40 kadın ve aynı sayıda sağlıklı gönüllü alındı. Serum $\mathrm{Zn}, \mathrm{Cr}$, $\mathrm{Mn}$, Foliküler stimüle edici hormon (FSH), Lüteinleştirici Hormon (LH), Dehidroepiandrosteron (DHEA-S), Tota Testosteron (TT), Seks hormonu bağlayıcı globulin (SHBG), insülin, glukoz, kolesterol, trigliserit, yüksek yoğunluklu lipoproteinler (HDL) ve düşük yoğunluklu lipoproteinler (LDL) konsantrasyonları analiz edildi. Bulgular: PKOS grubunda insülin, glukoz, trigliserit, DHEA-S düzeyleri kontrol grubuna göre anlamlı derecede yüksek iken, FSH ve Mn düzeyleri HOMA-IR grubunda kontrol grubuna göre anlamlı derecede düşüktü $(\mathrm{p}<0.05)$. Sonuç: Çalışmamızda serum eser elementleri ile PKOS arasında bir ilişki saptanırken, IR'nin dahil edilmesiyle ilişki düzeyi artmaktadır. Ayrıca, mangan eksikliği varlığında insülin direncinin doğrudan oksidatif strese yol açıp açamayacağını belirlemek için bu elementin takviyesinin etkilerini değerlendiren ek çalışmalara ihtiyaç olacağını da düşünmekteyiz.

Anahtar Kelimeler: İnsülin direnci, kobalt, krom, manganez, polikistik over sendromu
\end{abstract}

\section{ABSTRACT}

Objective: The study was investigate serum zinc $(\mathrm{Zn})$, chromium $(\mathrm{Cr})$, cobalt $(\mathrm{Co})$ and manganese $(\mathrm{Mn})$ concentrations in relation to hormone levels and polycystic ovary syndrome (PCOS)

Materials and Methods: Fourty women between 18-40 years of age diagnosed with PCOS. We also seleceted 40 healty volunteers as the control group. Serum $\mathrm{Zn}, \mathrm{Cr}, \mathrm{Mn}$, follicular stimulating hormone (FSH), luteinizing hormone (LH), Dehydroepiandrosterone sulfate (DHEA-S), total testosterone (TT), sex hormone binding globulin (SHBG), insulin, glucose, cholesterol, triglyceride, High Density Lipoprotein (HDL-C) and Low density lipoprotein (LDLC) concentrations were determined.

Results: Insulin, glucose, triglyceride, DHEA-S levels were significantly higher in the PCOS group than in the control group, while FSH and Mn levels were significantly lower in the HOMA-IR group than in the control group $(\mathrm{p}<0.05)$.

Conclusions: A possible association is perceptible in our study between some of serum trace elements and women with PCOS. The association attains a connotative level with the involvement of IR in it. Additional studies evaluating the effects of these elements supplementation would be required to confirm the hypothesis as well as to ascertain whether insulin resistance in the presence of manganese deficiency can directly lead to oxidative stress. Keywords: Chromium, cobalt, insulin resistance, manganese, polycystic ovary syndrome

\section{Yayın Bilgisi / Article Info:}

Gönderi Tarihi/ Received: 01/06/2019

Kabul Tarihi/ Accepted: 27/05/2020

Online Yayın Tarihi/ Published: 30/06/2020

Sakarya University, Faculty of Medicine,

Department of Medical Biochemistry, 6500, Sakarya, Turkey

Tel: +905064971615

Fax: +90-(264)-216 7519

E-mail: erdemcokluk@sakarya.edu.tr

*Atıf / Cited: Balahoroglu R, et.al. The Relationship Between Insulin Resistance and Trace Elements in Patients With Polycystic Ovary Syndrome. Online Türk Să̆llk Bilimleri Dergisi 2020;5(2):375-382. doi: 10.26453/otjhs.571510

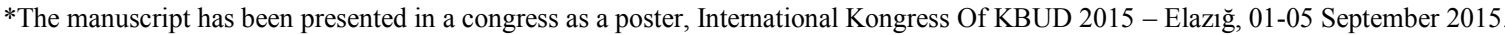




\section{INTRODUCTION}

About one in seven (9 to $18 \%$ ) of women in reproductive age suffer from policystic over syndrome (PCOS) in worldwide. It appears itself with reproductive, metabolic and psychosocial system disorders. ${ }^{1}$ It is obvious that the insulin resistance is associated with excessive weight. However, lean women are also often suffering from this complex disorder. Hyperandrogenism is accompanied by luteinized hormone by releasing sex hormone binding globulin and ovarian steroidogenic enzymes from the liver. Hyperandrogenism caused by luteinising hormone (LH) has a synergistic effect on steroidogenic enzymes in the ovaries and on the sex hormone binding globulin (SHBG) in the liver. The influence of insulin resistance on adrenal and ovarian steroidogenesis has a crucial effect on hyperandrogenemia of patients with PCOS. Biochemical evaluation of hyperandrogenism is usually done by determination of total testosterone (TT), SHBG and dehydroepiandrosterone sulphate (DHEAS) levels in the serum. High androgen levels may negatively affect follicular development. ${ }^{2}$ There is usually an atherogenic pattern in PCOS where high triglycerides, cholesterol, low-density lipoprotein cholesterol concentrations are observed. It can be said that the changes in lipid metabolism detected in PCOS are the effects of insulin resistance, elevation of androgen and obesity. ${ }^{3}$ Trace elements are components with physiologically significant effect on the human body at low or ultra low levels. Zinc (Zn), Chromium (Cr), Manganese $(\mathrm{Mn})$, and Cobalt $(\mathrm{Co})$ are trace elements which have been related to insulin resistance, obesity, oxidative damage and reproductive disorders. ${ }^{4}$ Zinc is an important cofactor for more than 300 enzymes in different mechanisms and also associated with insulin action and glucose metabolism such as synthesis, regulation and protecting of structure. ${ }^{5}$ Chromium supplementation given to animals with genetic or nutritional insulin resistance increases insulin action, enhances the effect of insulin on the signal pathway, reduces the effects of insulin signaling regulators, increases AMPK activity, regulates intracellular glucose uptake and reduces oxidative stress. Together with attention to the wide safety profile, these beneficial effects of chromium is believed to be an adjunct therapy that can be used in the control of insulin resistance or diabetes. ${ }^{6,7}$ Manganese is a trace element in the structure of effective metalloenzymes and proteins in cell metabolism and oxidative stress regulatory pathways, and is also thought to be a PCOS association with the cause of the effect of oxidative stress. ${ }^{8}$ Previous studies have reported that cobalt chloride $\left(\mathrm{CoCl}_{2}\right)$ has reducing effect of blood glucose level and of metabolic glucose production, or an enhancing effect of cell glucose uptake, or a integration of both process. However, cobalt increases glucose transport 1 expression (GLUT1) and inhibits gluconeogenesis, as well as reducing lipid peroxidation in numerous organs like liver, kidney and heart of diabetic rats. ${ }^{9,10}$ In the study, it was aimed to determine the relationship between serum concentrations of $\mathrm{Zn}, \mathrm{Cr}, \mathrm{Co}, \mathrm{Mn}$ levels and PCOS. It is also desired to determine the relationship between insulin resistance and trace elements in PCOS

\section{MATERIALS AND METHODS}

Subjects: Between September 2013 and September 2014, individuals with PCOS who were admitted to the endocrinology department in Van Yuzuncu Y1l University, Dursun Odabas Medical Center were included in the research. The research was approved by the local Clinical Research Ethics Committee (Date: 09/05/2013, decision no:3). The presence of two of the three characteristics was used to diagnose PCOS: chronic anovulation/oligomenorrhea, hyperandrogenemia (biochemically) and more than 12 follicles on ultrasound. General reasons such as prolactinoma, congenital adrenal hyperplasia, Cushing's syndrome and ovarian / adrenal tumors that virilizing were not used in the diagnosis, which 2004 Rotterdam ESHRE / ASRM sponsored PCOS Consensus Workshop Group recommend. ${ }^{11}$ This study included forty women between 18- 40 years of age diagnosed with PCOS (group with PCOS). Also, we randomly selected 40 volunteers from the endocrinology clinic for control group. There was no sonographic findings of hyperandrogenism, infertility or PCOS symptoms in the control group. Women exposed to heavy metal and trace elements were not included in the control group. Patients who had a records of hypertension, diabetes, or cardiovascular circumstance, who used oral/contraceptives, antiandrogens, insulin sensitisers or who could have an impact on clinically and/or biochemically parameters were count out of the study. Individuals did not smoke and did not carry a risk of pregnancy. Those with mild oligomenorrhea were examined in the first 10 days after the start of menstruation and those with severe oligo- / amenorrhea were randomly examined. A voluntary consent form including the aims 
and procedures of the study was explained and signed to all individuals. IR, fasting glucose / insulin ratio (GIR) was estimated by homeostasis model assessment (HOMA). The HOMA formula was computed as [fasting insulin concentration $(\mu \mathrm{U} / \mathrm{mL})$ $\times$ fasting glucose concentration $(\mathrm{mg} / \mathrm{dL})] / 405$ with a cut off point of 2.7. ${ }^{12}$

Materials: Milli-Q (Millipore, Bedford, MA) deionized water was used for trace element measurement. All reagents used in the HPLC system had an analytical reagent grade (Triton X-100, Sigma-Aldrich, USA and $\mathrm{HNO}_{3}$, Merck, Germany). Standard solutions were prepared by their prescripts. Care was taken to avoid heavy metals and trace element contamination in serum sampling, storage and analysis. Before, centrifuge tubes, plastic bottles, glassware and cryogenic vials were used 24 hours $10 \%$ (v/v) $\mathrm{HNO}_{3}$ incubation and five times deionized water rinsing and desiccation applied respectively.

Sample Analysis: Blood samples collected on the 2 nd or 3rd day of the menstrual cycle were centrifuged and the serum was separated, portioned and freezed at $-80^{\circ} \mathrm{C}$ until the day of analysis. Serum $\mathrm{Zn}$, $\mathrm{Cr}$, Mn were determined atomic absorption spectroscopy (AA-7000 Atomic Absorption Spectrophotometer, Shimadzu-Japan). Serum $\mathrm{Zn}, \mathrm{Cr}$ and $\mathrm{Mn}$ levels were calculated after determining the absorbance and concentrations on the appropriate calibration curve obtained from standard solutions. Co levels were determined with inductively coupled plasma-mass spectrometry (Thermo Scientific ICAP 6000 Series-ICAP 6300, Duo-England), by Goullé et al. method. ${ }^{13}$ Calibration was performed with supporting calibrators before the measurements and Co levels were calculated as the manufacturer's instructions. Serum FSH, LH, DHEA-S, TT, SHBG, insulin levels were measured with chemiluminescent microparticule immunometric assays (Abbott Diagnostic Architect İ2000 SR, USA). Serum glucose, total cholesterol, triglyceride, high-density lipoprotein cholesterol (HDL-C), and low-density lipoprotein cholesterol (LDL-C) concentrations were determined by Architect System Abbott Plus CI $16200 \AA$ analyzer (Abbott Diagnostic Architect Plus CI 16200, USA).

Statistical analysis: Outcomes were declared as mean and SD. The change in among to variables was determined by Student's $t$ test. The relationship between the parameter was estimated using Pearson correlation coefficient. $\mathrm{p}<0.05$ was expressed statistically significant. Statistical Package Software (ver.
15.0; SPSS, USA) was used to evaluate the statistical examinations.

\section{RESULTS}

The difference was not statistically significant between the PCOS groups in age or weight so this section did not mention in the text as a table $(p>0.05)$. The comparison of serum levels of biochemical and hormone parameters between the PCOS and control groups are demonstrated in Table 1. Serum concentrations of insulin and DHEAS were greater, in PCOS patients than the controls $(p<0.05)$. The difference between serum SHBG, testosterone and LH concentrations was not significant between groups $(\mathrm{p}>0.05)$. As expected, a high LH / FSH ratio was present in the PCOS group. Fasting As expected, glucose / insulin ratio and HOMA-IR $(p<0.05)$ values in PCOS group were higher comparison to the control $(p<0.05)$. Serum glucose and triglyceride concentrations were significantly lower in the control group than in the PCOS group $(p<0.05)$, whereas cholesterol and HDL-cholesterol concentrations were not significant ( $\mathrm{p}>0.05$ ).

The comparison of serum levels of trace elements between PCOS patients and healthy individuals are presented in Table 2. Groups serum $\mathrm{Cr}, \mathrm{Zn}$ and $\mathrm{Co}$ concentrations were not significantly differences $(\mathrm{p}<0.05)$. Only the Mn levels of patients group was lower with respect to the control group $(p>0.05)$. Furthermore, there were positive correlation between DHEA-S and insulin with glucose levels in PCOS group $(\mathrm{r}=0.870, \mathrm{p}<0.05)$.

\section{DISCUSSION AND CONCLUSION}

Compensatory hyperinsulinemia associated with insulin resistance can be seen in people with both weak and obese PCOS. ${ }^{14}$ In PCOS patients, HOMA evaluated insulin resistance indicate a high correlation between insulin resistance assessed by euglycemic hyperinsulinemic clamp or iv glucose tolerance test. ${ }^{15}$ In the study, FG/I ratio and HOMA-IR were used in insulin resistance estimation. Previous studies indicate that, the cut-off value of HOMA which is demonstrate the insulin resistance in Turkey is between 2.4-2.7 because of ethnicity and regional changes. ${ }^{16}$ Bagis et al. ${ }^{17}$ showed a threshold of 2.24 for HOMA in PCOS patients and found that 52 (46.4\%) of 112 patients had insulin resistance. Turan et al. ${ }^{18}$ determined $34 \%$ of PCOS in 89 patients. Cegil et al. ${ }^{16}$ determined the IR $66 \%, 54.2 \%$ and $32.2 \%$ according to HOMA, fasting glucose/insulin ratio and 2 nd hour OGTT respectively. These data 
are similar to the results of our study. In this study, we found that FG/I ratio and IR were significantly higher in the patient group when we used the predictive value of 2.7 to detect HOMA-IR in patients with PCOS $(p<0.05)$. The percentage of insulin resistance is $61 \%$ and $43.9 \%$ according to HOMA and fasting glucose/insulin index in PCOS patients, respectively and $7.5 \%$ and $5 \%$ in intervention group respectively. Approximately $50 \%$ to $60 \%$ of patients with PCOS are obese and obesity is still debating whether PCOS is a facilitating factor or a consequence of the disease. In addition, abnormal serum lipid profile of PCOS patients is reported to be close to $70 \%{ }^{19}$ Bagis et al. ${ }^{17}$ showed that $19 \%$ of PCOS patients had higher than $200 \mathrm{mg} / \mathrm{dL}$ total cholestrol levels, 71.1\% PCOS patients had lower than $50 \mathrm{mg} / \mathrm{dL}$ HDL cholestrol levels and $15 \%$ of PCOS patients had higher than $150 \mathrm{mg} / \mathrm{dL}$ triglyceride levels. The data showed that $7.3 \%$ of PCOS patients had higher than $200 \mathrm{mg} /$ dL total cholestrol levels, $68.3 \%$ PCOS patients had lower than $50 \mathrm{mg} / \mathrm{dL}$ HDL cholestrol levels and 26.8 $\%$ of PCOS patients had higher than $150 \mathrm{mg} / \mathrm{dL}$ triglyceride levels. These results complement the results of previous studies. ${ }^{17,19}$ Sreejayan et al. ${ }^{7}$ suggested that $\mathrm{Cr}$ may be beneficial in reducing insulin resistance and diabetes mellitus treatments. The chromium present in the cell enhances the insulin signal through insulin receptor kinase activity. ${ }^{8}$ Basaki et al. ${ }^{20}$ showed that the $\mathrm{Cr}$ levels in diabetes were higher and the $\mathrm{Zn}$ and $\mathrm{Cr}$ levels were lower than the control group. They have also linked this to the insulin effect of $\mathrm{Cr}$ in glucose metabolism. Karagün $^{21}$ indicated that low levels of plasma and erythrocyte $\mathrm{Cr}$ with a low level of urinary $\mathrm{Cr}$ might be result of negative $\mathrm{Cr}$ balance in patients with $\mathrm{DM}$ and also noted that low plasma and erythrocyte $\mathrm{Cr}$ levels may contribute to high glucose levels in diabetic patients by negatively affecting insulin function. To the extent of our knowledge this is the initial study that shows serum $\mathrm{Cr}$ concentration in patients with PCOS. Although there was a increase in Cr levels of PCOS patients, it was not significantly higher with respect to the healthy group $(p>0.05)$. In order to consolidate the findings obtained in this study and to obtain new perspectives, we suggest that more patients are included in the future studies. $\mathrm{Zn}$ is another important trace element which has catalytic, structural and regulatory functions in metabolism. However, $\mathrm{Cu}-\mathrm{Zn}$ is an antioxidant that is present in the SOD structure and protects the tissue

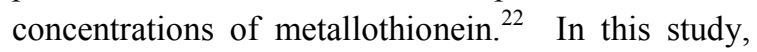
although serum $\mathrm{Zn}$ concentrations were determined as higher than the control but the highness was not significant $(p>0.05)$. Variable results have been reported in different studies in which $\mathrm{Zn}$ concentrations were determined. ${ }^{23-26}$ High serum Zinc concentrations in PCOS patients can be associated with increased insulin resistance and increased antioxidant capacity. $\mathrm{Zn}$, is known to have an antioxidant effect by participating in the structure of $\mathrm{Cu}-\mathrm{Zn}$ SOD, and the first phase of antioxidant defence mechanism is to increase the components of its structural elements. It may also need to further studies which have include to analyse of oxidative status of PCOS patients. Manganese is a trace element that functions in mechanisms that protect the body against oxidative damage. This function is achieved by the presence of Mn-containing SOD (MnSOD) enzyme as a cofactor in its activity. ${ }^{23}$ It reduces the high reactivity SOD ions to the less reactive hydrogen peroxidase compounds. Then the hydrogen peroxidase converts into water by catalase and peroxidase in mitochondrial matrix. ${ }^{27}$ Serum Mn concentration levels of PCOS patients were close to half of the concentrations determined in the control group. Based on this result, assuming that manganese intake levels are sufficient, there may be an indication that manganese may be consumed in the antioxidant defence system, including MnSOD, in the case of increased oxidative stress. Cobalt chloride $\left(\mathrm{CoCl}_{2}\right)$ has glycemia-lowering effects and decreased systemic glucose production. The expression of glucose transporter 1 (GLUT1) increased due to the efficacy of cobalt, resulting in a decrease in the activity of gluconeogenesis. ${ }^{28}$ In addition, Co is a heavy metal, which is caused to generate ROS formation indirectly, increases the production of free radicals in the DNA repair process, that contribute further DNA damage. ${ }^{29} \mathrm{Co}$ is also involved in the inhibition of gene expression and signal transduction pathway. ${ }^{29}$ Although we detected high levels of cobalt concentrations in PCOS patients compared to control group, we found that these high levels were not statistically significant $(p<0.05)$. Although we could not find any difference between PCOS and Co levels in our study, we think that, more detailed research should be planned to determine cobalt's effects on PCOS.

In conclusion: Finally, the prevalence of IR calculated on the basis of HOMA-IR measurement was found to be $61 \%$ in a small population of PCOS patients with randomly selected. Although IR is a common abnormal condition in PCOS, the fact that no predictive value is determined in people with 
PCOS avoid it from being a diagnostic criterion. The results of our study show that serum trace element concentration alternate may be present in people with PCOS. Whether the lack of these elements leads directly to oxidative stress should also be investigated in different studies examining the effects of element supplementation on PCOS patients. In addition, we think that SOD, catalase and cytochrome-c oxidase concentrations should be assessed in order to know their possible relationships with PCOS.

Ethics Committee Approval: Our study was approved by the Local Ethics Committee of Yuzuncu Yil University (Date: 09.05.2013, decision no: 03).

Conflict of Interest: No conflict of interest was declared by the authors.

Author Contributions: Concept - RB, MA, AKZ; Supervision -ZH, MRŞ; Materials -EÇ, AKZ; Data Collection and Processing - RB, MA, MRŞ; Analysis and Interpretation - ZH, EÇ; Writing - RB.

Peer-review: Externally peer-reviewed.

Funding: This research was funded Yuzuncu Yil University Scientific Research and Project Department (2013-SBEYL052)

\section{REFERENCES}

1. Teede HJ, Misso ML, Deeks AA, et al. Assessment and management of polycystic ovary syndrome: summary of an evidence-based guideline. The Medical Journal of Australia. 2011;195 (6):S65.

2. De Leo V, Musacchio M, Cappelli V, Massaro M, Morgante G, Petraglia F. Genetic, hormonal and metabolic aspects of PCOS: an update. Reproductive Biology and Endocrinology. 2016;14 (1):38. doi: 10.1186/s12958-016-0173-x

3. Cortón M, Botella-Carretero JI, López JA, et al. Proteomic analysis of human omental adipose tissue in the polycystic ovary syndrome using two-dimensional difference gel electrophoresis and mass spectrometry. Human Reproduction. 2007;23(3):651-661.

4. Spritzer PM, Lecke SB, Fabris VC, Ziegelmann PK, Amaral L. Blood Trace Element Concentrations in Polycystic Ovary Syndrome: Systematic Review and Meta-analysis. Biological trace element research. 2017;175(2):254-262.

5. Cruz KJC, de Oliveira ARS, do Nascimento Marreiro D. Antioxidant role of zinc in diabetes mellitus. World journal of diabetes. 2015;6 (2):333-337.

6. Savsatli Y, Ozcan A, Catal M, Seyis F, Akbulut M, Turumtay EA. Trace Elements In Bitter Melon (Momordica Charantia L.) And Their Distribution In Different Plant Parts. 2006.

7. Sreejayan N, Dong F, Kandadi MR, Yang X, Ren J. Chromium alleviates glucose intolerance, insulin resistance, and hepatic ER stress in obese mice. Obesity. 2008;16(6):1331-1337.

8. Chakraborty P, Ghosh S, Goswami S, Kabir SN, Chakravarty B, Jana K. Altered trace mineral milieu might play an aetiological role in the pathogenesis of polycystic ovary syndrome. Biological trace element research. 2013;152(1):9-15.

9. Siddiqui K, Bawazeer N, Scaria Joy S. Variation in macro and trace elements in progression of type 2 diabetes. The Scientific World Journal. 2014;2014:461591.

10. Yildirim O, Buyukbingol Z. Effect of cobalt on the oxidative status in heart and aorta of streptozotocin-induced diabetic rats. Cell biochemistry and function. 2003;21(1):27-33.

11. Rotterdam E, Group A-SPCW. Revised 2003 consensus on diagnostic criteria and long-term health risks related to polycystic ovary syndrome. Fertility and sterility. 2004;81(1):19-25.

12. Zheng G, Wang L, Guo Z, et al. Association of serum heavy metals and trace element concentrations with reproductive hormone levels and polycystic ovary syndrome in a Chinese population. Biological trace element research. 2015;167(1):1 -10 .

13. Goullé J-P, Mahieu L, Castermant J, et al. Metal and metalloid multi-elementary ICP-MS validation in whole blood, plasma, urine and hair: Reference values. Forensic Science International. 2005;153(1):39-44.

14. Celik C, Bastu E, Abali R, et al. The relationship between copper, homocysteine and early vascular disease in lean women with polycystic ovary syndrome. Gynecological Endocrinology. 2013;29(5):488-491.

15. DeUgarte CM, Bartolucci AA, Azziz R. Prevalence of insulin resistance in the polycystic ovary syndrome using the homeostasis model assessment. Fertility and sterility. 2005;83(5):14541460.

16. Cegil y. Research Of Hormon's And Insulin Levels In Patients With Polycystic Ovary Syndrome. 
Specialization Thesis, Edirne, Turkey.: Trakya University; 2009.

17. Bagis HT, Hacıvelioglu S, Haydardedeoglu B, et al. Prevalance Of Insulın Resıstance, Impaired Glucose Tolerans Test And Diabetes Mellitus In Women With Polcystic Ovary Syndrome; Analysis Of 235 Patients. Journal of Turkish Obstetric and Gynecology Society.2008; 5(2):99-104.

18. Turan V, Erdogan M, Yeniel Ö, Ergenoğlu M, Kazandi M. The assessment of biochemical, hormonal blood parameters and clinical symptoms of 89 polycystic ovarian syndrome patients. Ege Journal of Medicine. 2011;50(3):179-182.

19. Ovalle F, Azziz R. Insulin resistance, polycystic ovary syndrome, and type 2 diabetes mellitus. Fertility and sterility. 2002;77(6):1095-1105.

20. Basaki M, Saeb M, Nazifi S, Shamsaei H. Zinc, copper, iron, and chromium concentrations in young patients with type 2 diabetes mellitus. Biological Trace Element Research. 2012;148 (2):161-164.

21. Karagun BS, Temiz F, Ozer G, et al. Chromium levels in healthy and newly diagnosed type 1 diabetic children. Pediatrics International. 2012;54(6):780-785.

22. Stefanidou M, Maravelias C, Dona A, Spiliopoulou C. Zinc: a multipurpose trace element. Archives of toxicology. 2006;80(1):1-9.

23. Kurdoglu Z, Kurdoglu M, Demir H, Sahin H. Serum trace elements and heavy metals in polycystic ovary syndrome. Human \& experimental toxicology. 2012;31(5):452-456.

24. Vashum KP, McEvoy M, Milton AH, Islam MR, Hancock S, Attia J. Is serum zinc associated with pancreatic beta cell function and insulin sensitivity in pre-diabetic and normal individuals? Findings from the Hunter Community Study. PLoS One. 2014;9 (1):e83944. doi:10.1371/journal.pone.0083944

25. García OP, Ronquillo D, del Carmen Caamaño $\mathrm{M}$, et al. Zinc, iron and vitamins $\mathrm{A}, \mathrm{C}$ and $\mathrm{E}$ are associated with obesity, inflammation, lipid profile and insulin resistance in Mexican schoolaged children. Nutrients. 2013;5(12):5012-5030.

26. Chakraborty P, Goswami S, Rajani S, et al. Recurrent pregnancy loss in polycystic ovary syndrome: role of hyperhomocysteinemia and insulin resistance. PLoS One. 2013;8(5):e64446.

27. Ozden O, Park SH, Kim HS, et al. Acetylation of MnSOD directs enzymatic activity responding to cellular nutrient status or oxidative stress. Aging (Albany NY). 2011;3(2):102-117.
28. Saker F, Ybarra J, Leahy P, Hanson RW, Kalhan SC, Ismail-Beigi F. Glycemia-lowering effect of cobalt chloride in the diabetic rat: role of decreased gluconeogenesis. American Journal of Physiology-Endocrinology and Metabolism. 1998;274(6):984-991.

29. Jomova K, Valko M. Advances in metal-induced oxidative stress and human disease. Toxicology. 2011;283(2-3):65-87. 
Table 1. Comperison of groups in terms of hormonally parameters.

\begin{tabular}{|l|c|c|}
\hline Parameters & $\begin{array}{c}\text { Healthy Control Group } \\
(\mathbf{n}=\mathbf{4 0})\end{array}$ & $\begin{array}{c}\text { Patients Group } \\
(\mathbf{n}=\mathbf{4 0})\end{array}$ \\
\hline DHEA-S ( $\boldsymbol{\mu g} / \mathbf{d L})$ & $224.65 \pm 102.47$ & $349.74 \pm 124.98^{*}$ \\
SHBG (nmol/L) & $55.33 \pm 43.08$ & $40.32 \pm 34.47$ \\
Insulin (mg/dL) & $7.55 \pm 3.84$ & $24.22 \pm 21.86^{*}$ \\
FSH (mIU/mL) & $6.98 \pm 7.90$ & $4.05 \pm 1.52^{* *}$ \\
LH (mIU/mL) & $7.80 \pm 10.64$ & $7.76 \pm 5.33$ \\
LH/FSH (>1.5) & $1.26 \pm 1.20$ & $6.57 \pm 2.97$ \\
Testosterone (nmol/L) & $1.50 \pm 0.58$ & $1.72 \pm 0.61$ \\
TG (mg/dL) & $81.13 \pm 34.90$ & $118.22 \pm 65.60^{* * *}$ \\
HDL-C (mg/dL) & $44.33 \pm 9.58$ & $45.00 \pm 10.57$ \\
T-Cholestrol (mg/dL) & $148.40 \pm 30.20$ & $161.76 \pm 34.23$ \\
FG(mg/dL) & $71.78 \pm 9.20$ & $84.15 \pm 12.52^{*}$ \\
HOMA-I (>2.7) & $1.351 \pm 0.764$ & $5.066 \pm 4.445^{*}$ \\
FG/Insulin (<4.5) & $11.446 \pm 4.885$ & $6.516 \pm 4.510^{*}$ \\
\hline TG:triglyseride; FG:fasting glucose; ${ }^{*} p<0.001 ;{ }^{* *} p<0.05 ; * * * p<0.01$.
\end{tabular}


Table 2. Comparison of trace elements levels between PCOS and control groups.

\begin{tabular}{|l|c|c|}
\hline Parameters & $\begin{array}{c}\text { Healthy Control Group } \\
(\mathbf{n}=\mathbf{4 0})\end{array}$ & $\begin{array}{c}\text { Patients Group } \\
(\mathbf{n}=\mathbf{4 0})\end{array}$ \\
\hline $\mathbf{C r}(\boldsymbol{\mu g} / \mathbf{L})$ & $0.1684 \pm 0.1174$ & $0.2160 \pm 0.1502$ \\
$\mathbf{Z n}(\mathbf{m g} / \mathbf{L})$ & $3.9304 \pm 2.2162$ & $4.8815 \pm 3.2364$ \\
$\mathbf{C o}(\boldsymbol{\mu g} / \mathbf{L})$ & $0.1375 \pm 0.1108$ & $0.2864 \pm 0.1897$ \\
$\mathbf{M n}(\boldsymbol{\mu g} / \mathbf{L})$ & $0.8068 \pm 0.4248$ & $0.5787 \pm 0.4289^{*}$ \\
\hline
\end{tabular}

${ }^{*} p<0.05$. 